\title{
PLANT METABOLISM IN THE CONDITIONS OF SPACE FLIGHT
}

\section{Ye. IVANOVA, A. A. ANTONYAN, T. A. DERENDIAYEVA, A. L. MASHINSKI, G. I. MELESHKO'1, T. IVANOVA ${ }^{2}$, I. STOYANOV ${ }^{3}$ \\ ${ }^{1}$ Institute for Biomedical Problems, Health Department RF, Moscow, Russia, \\ ${ }^{2}$ Institue for Space Research, Bulgarian Academy of Science, Sofia, Bulgaria, \\ ${ }^{3}$ Plant Physiology Institute, Bulgarian Academy of Science, Sofia, Bulgaria}

Received June 5, 1995

Accepted June 6, 1996

\begin{abstract}
I. Ye. Ivanova, A. A. Antonyan, T. A. Derendiayeva, A. L. Mashinski, G. I. Mele shko, T. Ivanova, I. Stoyanov: Plant Metabolism in the Conditions of Space flight. Acta vet. Brno 1996, 65: 11-17.

For the first time, vegetation of plants of radish and cabbage from a seed to the harvest age was performed in the conditions of space flight. The duration of the experiment was 54 days. The growth and development of the plants lagged behind the Earth control, and the harvest was by 2-5 times lower than in the control. The radish plants formed roots.

Some deviations were found in the plant metabolism. At a practically similar composition of the biomass of the experiment and control plants, the experimental ones manifested some differences in the fractional composition of several compounds (nitrogen, phosphorus, carbohydrates, lipids) at the account of decrease of compounds playing the primary role in the energy exchange of the cell.

A tendency was noticed towards a decrease of potassium content in the cells of the experiment plants. For other biogenic elements (iron, manganese, copper, zinc) there were no differences between the experiment and control.

The obtained results did not show any difference in the plant metabolism which could testify to its impairment resulting in the death of the plants or impossibility of maintaining trophic connections in the future life support systems.
\end{abstract}

Conservatory, radish, cabbage, biogenic elements, pigments, metabolism

The study of growth and development of plants in the conditions of space flight began more than 30 years ago. By the present time, a vast experimental material has been gathered, which is generalized and discussed in the monograph by Parf y on ov (1988). He wrote: "If we limit ourselves by the processes described in terms of molecular biology, biochemistry and genetics, we should conclude that the elementary biological processes in plants go normally in the conditions of weightlessness." It has been shown that all the stages of plant development may take place normally in weightlessness: germination of seeds and formation of initial organs, differentiation and formation of somatic tissues, laying of the generative cells, differentiation of the generative cells, blooming, fertilization, embryogenesis and ripening of the seeds. Such conclusions were made from the results of experiments made with different plants and in different times by means of "questioning" of various stages of ontogenesis in the conditions of space flight. Only the results of the experiment with the tube culture of Arabidopsis allow to hope that it is really so. In this experiment, made on board the station "Salyut-7", it was possible to perform the whole cycle of individual development (M erkis and Laurinavichus 1983).

Growing plants in the conditions of space flight presents a number of difficulties. Usually, plants perish at the stage of early or late sprouts due to the damage of the root system. The roots are the most sensitive and vulnerable organs of the plants, they are most closely connected with the conditions of the environment, that is why they are adapted to exclusively stable conditions (Parf y on ov 1988). The scientists have not yet managed to create such 
conditions due to the absence of an optimal construction of a conservatory for growing plants in weightlessness. That is why the metabolism of plants in the conditions of space flight is studied rarely. Only its separate aspects have been studied using wheat and peas sprouts of different ages (L a u rin a vi ch u s et al. 1984; M a shin s ki et al. 1991).

The goal of this paper si studying the biological material by some biochemical indices embracing the main metabolic processes of the plants grown in weightlessness from seed to the fertile age.

\section{Materials and Methods}

On board the station "Mir", a mutual experiment with higher plants was held by Soviet and Bulgarian scientists. The objects were such plants as radish Raphanus sativus and leaf cabbage Brassica pekinensis. The choice of the object was conditioned not only by the interests of gravitational biology, but also by the intentions to use the plants in the space crews life support systems. For growing the plants, the conservatory "Svet" was used, designed together with Bulgarian specialists and built in the Bulgarian Institute for Space Research. The conservatory worked in automatic regime with stabilization of temperature, substratum humidity, and air. The crop area was $0,1 \mathrm{~m}^{2}$, the illumination was $40 \mathrm{~W} / \mathrm{m}^{2} \mathrm{FAR}$. As a substratum, the salt-saturated natural zeolite "balkanine" was used. The construction of the conservatory and the principle of its work were described earlier (I va n ov a et al. 1991). The ground control was performed with the use of the same substratum at the same parameters of the environment which were transmitted by telemetry from the "Mir" station. After moistening the conservatory substratum on the "Mir" station, the seeds of the crops gave food sprouts on the 3-4th day, and on the 54th day of vegetation they were taken to the laboratory on the day of landing of the apparatus sent down; they were in special packing preventing them from fading. Part of the biological material was lyophilized and subjected to analysis by the main biological indices, embracing the basic metabolic processes.

For the analysis, one plant of radish and one plant of cabbage were received; Tables 1-3 give the average data from three analyses by each index.

\section{Results}

For the first time, in the conditions of space flight the vegetation of plants was performed, from the seed to the harvest age. The radishes gave root-crops. The growth, development and morphological characteristics of the plants were described before (I v a n o v a et al. 1990). Here we can say that the general image of the flight plants corresponded to that of the control ones, but they lagged considerably behind in growth and phenological part of the development. For instance, the control radish plants, in accordance with their actual age, passed to the phase of pedicle formation, which did not happen in the flight plants. By the end of the experiment (54th day) they continued to vegetate. The productivity by the increase of dry matter for the overground part of the plants was by 5-10 times lower than the control

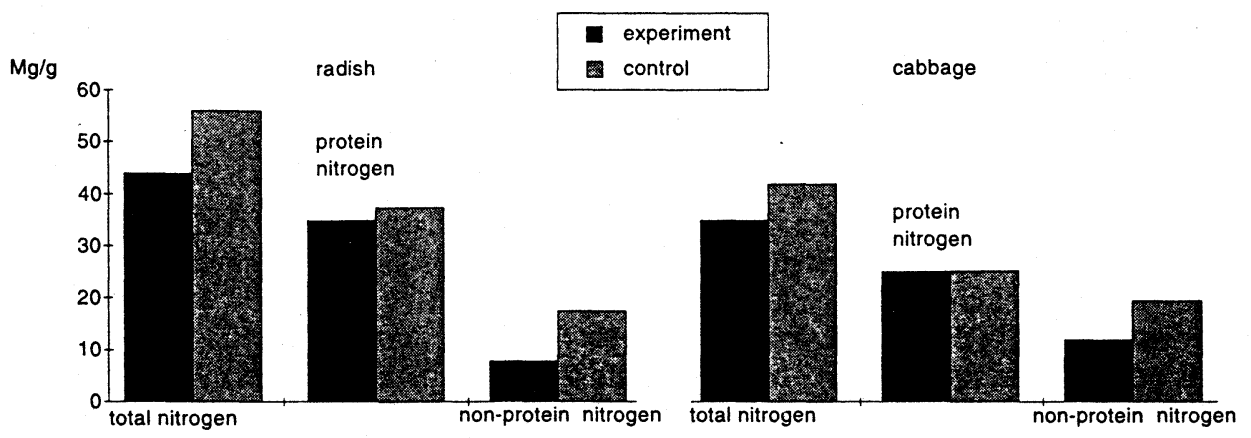

Fig. 1. The content of different nitrogen forms in the composition of radish and cabbage biomass. Full columms experiment, hatched columns - control. 
of radish and salad, respectively. For the root crops of radish, it made up about $60 \%$ of the control. Here we shall confine ourselves to these data, in order to make it clear what plants' metabolism is meant.

The content of biogenic elements in the composition of the biomass of radish and cabbage plants, is shown in Fig. 1.

The content of nitrogen in the biomass of the plants grown in the conditions of space flight, was obviously lower than the control and made up $80-85 \%$ of the control, respectively, for the radish and cabbage tops. These data correspond to those obtained earlier for the peas sprouts (Laurinavichus et al. 1984).

The functioning of nitrogen compounds (Fig. 1) has shown that the difference is mainly conditioned by the low content of non-protein nitrogen fraction in the experiment variants of the biomass. In proportion to the control, it was 49,7 and $66,1 \%$ for radish and cabbage, respectively. The fraction of protein nitrogen was the same as in the control, and made up 96 and $100 \%$ of the control for radish and cabbage, respectively. The considerable decrease of the fraction of non-protein nitrogen in the composition of the cells in the flight conditions was noted earlier in Chlorella (M e le sh ko et al. 1986).

Thus, in spite of the decrease of the content of total nitrogen in the experiment variants as compared with ground control, the content of constitutional protein in the biomass was the same as in the control and in the data of many years research. Its content was $20-23 \%$ for radish and about $15 \%$ for cabbage.

The content of phosphorus in the plants grown in weightlessness did not differ from the control (Fig. 2) and amounted to 91,1 and $88,7 \%$ of the control for the leaves of radish and cabbage respectively. In the root crops of radish, an increased content of phosphorus was found - $135 \%$ of the control. The fractioning of the phosphorus compounds (only for leaves) showed that there was a difference between the experiment and the control in the content of labile and stable compounds. The content of the latter in the flight variants was higher than the control by $50-100 \%$ for radish and cabbage, respectively. This corresponds to the considerably smaller rate of growth of the flight plants as compared to the ground control.

In the biomass of the flight samples of the radish plants (leaves and root-crops) and cabbage (leaves) a considerable decrease of potassium content was found. It amounted to 65.5 and $72 \%$ of the control, respectively. (Fig. 2, 3). For sodium an opposite picture was observed. Its content in the experiment samples was higher than the control - 183
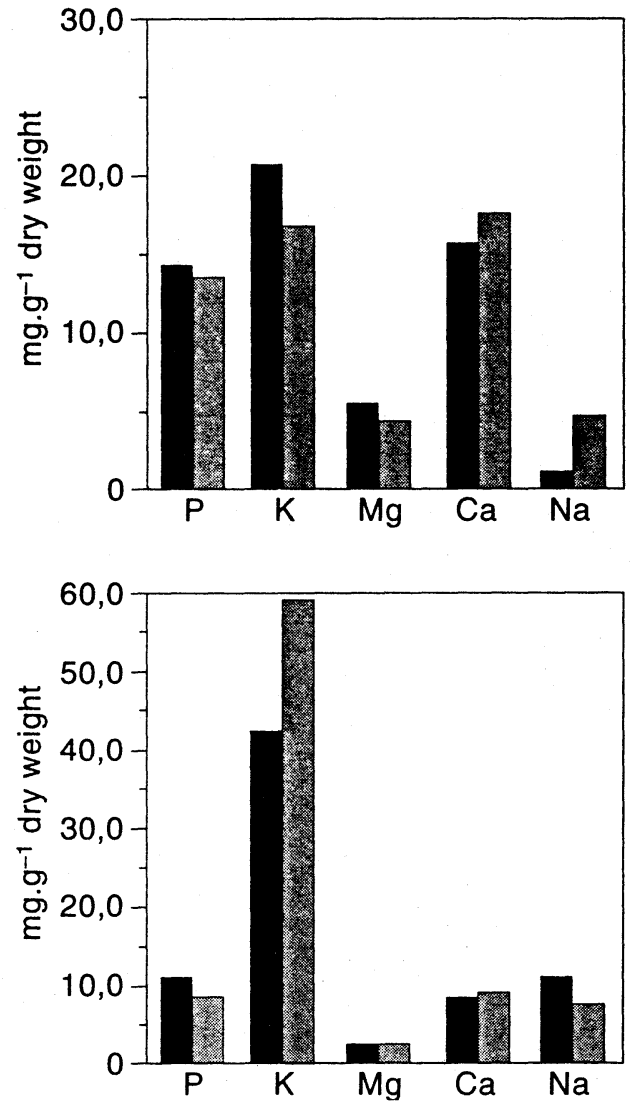

Fig. 2. The content of biogenic elements in the composition of radish (upper panel - leaves, bottom panel roots). For legend see Fig. 1. 


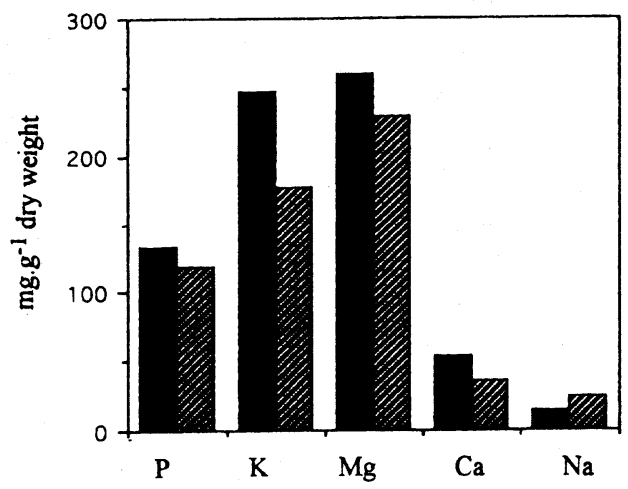

Fig. 3. The content of biogenic elements in the composition of cabbage biomass. For legend see Fig. 1.

and $150 \%$ for the leaves and roots of radish and $166 \%$ of the control for cabbage. The competitive relations between these elements in process of their being absorbed by the roots, take place also in terrestrial conditions, but here potassium is preferred. Sodium is present in the biomass in small quantities. Perhaps some scientists are right in their supposition that in the process of plant growing in the conditions of space flight, the metabolic control of the root cells becomes weaker in the plants, and as a result, the process of selective input of ions is broken (Laurinavichus et al. 1984).

For other biogenic elements, including some microelements (iron, manganese, copper, zinc), there was no difference between the experiment and the control for both plant species. These results differ from those obtained earlier in the wheat sprouts (Laurinavichus et al. 1984). There was no considerable difference between the experiment and the control in the content of cinders either. The results of the given experiment make it possible to suppose that the need of the plants in biogenic elements in the conditions of space flight will be close to that in terrestrial conditions, and as a consequence, the nutritive mediums and the correcting solutions will hardly undergo considerable changes.

Table 1

The content of carbohydrates and their main fractions in the leaves of radish grown in weightlessness and in ground control

\begin{tabular}{lcccccc}
\hline \multirow{2}{*}{$\begin{array}{l}\text { Experiment } \\
\text { variants }\end{array}$} & \multicolumn{5}{c}{ Carbohydrates and their fractions \% dry weight } \\
\cline { 2 - 7 } & sum & $\begin{array}{c}\text { alcohol } \\
\text { soluble }\end{array}$ & $\begin{array}{c}\text { low } \\
\text { molecule }\end{array}$ & starch & hemicellulose & cellulose \\
\hline experiment & 25.3 & 4.8 & 2.2 & 14.9 & 1.9 & 1.5 \\
control & 27.4 & 3.3 & 2.3 & 18.4 & 1.6 & 83.0 \\
\hline$\%$ of control & 92.0 & 145.0 & 95.0 & 81.0 & 1.0 & 83 \\
\hline
\end{tabular}

The carbohydrates and their composition for the radish leaves are given in Table 1 . By the sum total of carbohydrate, no difference was found between the experiment and the control. As for the fractional composition, there is a considerable difference between the experiment and the control. In the flight variant there is an obvious decrease of the content of starch $(81 \%$ of the control) and cellulose (83\% of the control), while the content of alcohol soluble sugars and hemicellulose is increased. Such a picture may be considered as the result of the reinforcement of the hydrolytic processes in the cells, which was also pointed out by other authors, who had obtained similar results with peas sprouts grown in the conditions of space flight (L a u ri n a vich us et al. 1984). As for the composition of carbohydrates, a difference between the experiment and the control was found only in the content of low-molecule carbohydrates.

The study of the pigment and lipid composition of the assimilating tissues of radish and cabbage grown in the conditions of space flight, were of special interest, for in all the previous studies of metabolism of algae and sprouts of higher plants, the changes had been found in this very complex. 
In Table 2, the data on the content of the main groups of fatty acids of lipids in radish and cabbage are presented. A considerable difference was found in the total content of fatty acids. Their quantity in the experiment was much higher than in the control, and made up 138 and $172 \%$ of the control for radish and cabbage respectively, at the content of total lipids being practically the same. Other indices of fatty acids composition (the content of the main groups of fatty acids of lipids, the values, of correlation between the main groups) either were the same as the control, or had a contradictory character.

Table 2

The content of the main groups of fat acids of lipids in radish and cabbage grown in weightlessness and in ground control (\% of the sum)

\begin{tabular}{|c|c|c|c|c|c|c|}
\hline \multirow[t]{2}{*}{ Fatty acids } & \multicolumn{2}{|c|}{ Radish } & \multicolumn{4}{|c|}{ Cabbage } \\
\hline & control & experiment & $\%$ of control & control & experiment & $\%$ of control \\
\hline saturated & 14.4 & 15.6 & 108.0 & 22.8 & 19.9 & 87.2 \\
\hline non-saturated & 85.6 & 84.4 & 97.3 & 77.2 & 80.1 & 103.6 \\
\hline poly-unsaturated & 64.3 & 59.5 & 92.5 & 55.7 & 63.1 & 114.5 \\
\hline $\begin{array}{l}\text { monoene } \\
\text { total content } \\
\text { of fatty acids }\end{array}$ & 21.5 & 28.0 & 103.0 & 22.4 & 17.1 & 76.3 \\
\hline $\begin{array}{l}\text { mg/g dry weight } \\
\text { saturated }\end{array}$ & 56.7 & 78.8 & 137.6 & 13.9 & 24.6 & 177.0 \\
\hline $\begin{array}{l}\text { un saturated } \\
\text { polyene }\end{array}$ & 0.17 & 0.18 & & 0.29 & 0.25 & \\
\hline monoene & 3.0 & 2.1 & & 2.6 & 3.6 & \\
\hline
\end{tabular}

No considerable difference was found in the content of the basic pigments either (Table 3). The total quantity of the pigments, the sum of chlorophylls and carotinoids were the same as in the control. Thus, the given results obtained for grown-up plants, did not confirm the data obtained earlier for sprouts of wheat and peas, and for algae about the considerable decrease of pigments in plants grown in space conditions, and the conclusions that the factors of the space flight stimulate the free radical processes of destruction of lipids and pigments in plants (Laurinavichus et al. 1984; Mashinski et al. 1991; Meleshko et al. 1986).

Table 3

The composition of pigments of the plants grown in the conditions of space flight and in ground control

\begin{tabular}{lcccc}
\hline Plant species & Experiment variant & \multicolumn{3}{c}{ Content of pigments, mg/g dry weight } \\
\cline { 3 - 5 } & & sum total of pigment & sum of chlorophylls & sum of carotinoids \\
\hline radish & experiment & 9.30 & 8.12 & 1.20 \\
& control & 9.96 & 8.52 & 1.43 \\
\hline \% of control & & 96.0 & 95.0 & 84.0 \\
\hline cabbage & experiment & 5.04 & 4.28 & 0.75 \\
& control & 4.31 & 4.30 & 0.68 \\
\hline$\%$ of control & & 116.0 & 100.0 & 110.0 \\
\hline
\end{tabular}

In conclusion it should be noted that the deviations found in some characteristics of the metabolism of vegetables (in protein, carbohydrate, lipid exchange, as well as in consuming potassium and sodium) cannot be explained by the results of one experiment, especially as the plants lagged considerably behind in their growth, development, and their productivity was much lower than in the control. Besides, some differences between the experiment and the control could appear due to the fact that the comparison of the characteristics was 
obtained at different stages of ontogenesis (age dynamics). This difference in the plants can indicate somed difference in physiological and ecological conditions of the plants growth in flight and in ground control, but they cannot concern the initial, direct influence of weightlessness. The latter has not yet been found either in separate organisms, of in populations (Parfy onov 1984; Tairbekov 1987; Meleshko et al. 1986).

The only clear fact today is the absence of impairments of the plant metabolism grown in space flight, which could bring about the death of the plant or showed that it was impossible to maintain trophic connections in the future life support systems.

We think that as long as the normal productivity is not obtained with the complete ontogenesis of plants - and this must be the only way to find out whether the conditions of growth are optimal - a convincing interpretation of all the effects found on all levels, in either difficult, or impossible.

\section{Metabolizmus rastlín v podmienkach vesmírneho letu}

Prvýkrát bola v kozmických podmienkach vypestovaná redkovka a kapusta zo štádia semena až po štádium zberu. Experiment trval 54 dní. Rast a vývoj rastlín sa oneskoril v porovnaní s vývojom na Zemi a úroda bola 2-5-násobne nižšia. Redkovky zapustili korene.

V metabolizme rastlín boli zistené niektoré zmeny. Zloženie biomasy experimentálnych a kontrolných rastlín bolo podobné. Experimentálna biomasa vykazovala však určité rozdiely vo frakčnom zložení niektorých látok (dusík, fosfor, sacharidy, lipidy) na úkor poklesu tých, ktoré majú primárnu úlohu pri výmene energie bunky.

Bola pozorovaná tendencia znižovania obsahu draslíka v bunkách experimentálnych rastlín. U iných biogénnych látok (železo, mangán, međ, zinok) neboli pozorované rozdiely medzi experimentom a kontrolou.

Získané výsledky nepreukázali rozdiely v rastlinnom metabolizme, ktorý by svedčil o jeho poruchách, vedúcich $\mathrm{k}$ úhynu rastliny, alebo o nemožnosti plnit trofickú funkciu v budúcom biologickom systéme zabezpečenia života.

\section{Метаболизм растений в условияй космического полета}

Впервые в условиях космического полета осуществлена вегетация растений редиса и капусты от семени до урожайного возраста. Общая длительность эксперимента 54 суток. Рост и развитие растений отставали от контроля, а урожая был 2-5 раз ниже контроля. У растений редиса получены корнеплоды.

Обнаружены некоторые отклонения в метаболизме растений. При практически одинаковом составе биомассы опытных и контрольных растений у опытных выявлены изменения во фракционном составе отдельных соединений (азота, фосфора, углеводов, липидов) за счет уменьшения соединений играющих первостепенную роль в энергетическом обмене клетки.

Выявлена тенденция к снижению содержания калия в повышению содержания натрия в клетках опытных растений. Для других биогенных элементов (железо, марганец, медь, цинк) различий между опытом и контроле не обнаружено.

Полученные результаты не выявили какой-либо разницы в метаболизм растений, которая свидетельствовала о его нарушении, конечным итогом которого была бы гибель растений или невозможность обеспечения трофических связей в будущих замкнутых экологических системах. 


\section{References}

IVANOVA, T., SAPUNOVA, S., DANDOLOV, I., KOSTOV, T., BERKOVICH, Y. A., MASHINSKI, A. 1990:Current Trends in Cosmic Biology and Medicine, Ivanka pri Dunaji, CSFR, pp. 281-286

IVANOVA, T., SAPUNOVA S., DANDOLOV, I., KOSTOV, P., BERKOVICH, Y. A., MASHINSKI, A. L. 1991:Current Trends in Cosmic Biology and Medicine. Ivanka pri Dunaji, pp. 179-185

LAURINAVICHUS R. S., YAROSHUS, A. V., MARCHUKAITIS, A., SHVIANEDENE, D. V., MASHINSKI, A. L. 1984: In: Biologicheskiye issledovaniya na orbitalnych stanciyach „Saliut“, Moskva, pp. 96-102

MASHINSKI, A. L., ALIOCHINA, T. P., BOZHKO, A. N., DERENDIAYEVA, T. A., IVANOVA, I.Ye.1991:Kosmicheskaya biologia i aviakosmicheskaya medicina, I., 25:39-41

MELESHKO, G. I., SHEPELEV, Ye.Ya., KORDIUM, V. A., SETLIK, I., DOUHA, J. 1986: In: Resultaty medicinskich issledovanij, vypolnennych na orbitalnom nauchno-issledovatelskom komplekse „Saliut-6Soyuz“", Nauka, pp. 269-380

MERKIS, A.I., LAURINAVICHUS R. S. 1983: Doklady AN SSSR, 271:509-512

PARFYONOV, G. P. 1988:Nevesomost i biologicheskiye processy. Problemy kosmicheskoy Biologii, 57, Nauka, Moskva

TAIRBEKOV, M. G. 1987:Phisiologicheskyie mechanismy adaptacii svobodnozhivushih i rastitelnych kletok k izmenennoy sile tyashesti. Moskva , Autoref. diss. doct. biol. nauk, 47 p. 